\title{
Reforma Protestante: uma caminhada de 500 anos
}

Recebido: 14/06/2016. Aprovado: 31/07/2016.

\section{Claudir Burmann*}

Resumo: A Reforma Protestante impactou o Cristianismo ocidental com uma divisão, cuja repercussão tem perpassado diversos âmbitos ao longo dos últimos 500 anos. Como seria o Cristianismo se a Reforma Protestante não tivesse ocorrido? Evidentemente, não há como responder. Certo é que a Reforma Protestante foi, de alguma maneira, favorecida por fatores conjunturais do século $X V I$, que ampliaram sua repercussão. Tais fatores fizeram com que o protesto inicial de Martim Lutero através de 95 teses acerca da venda de indulgências tivesse um alcance não imaginado. A partir dali, foi-se consolidando um novo modo de compreender o agir de Deus. Ao mesmo tempo, uma nova forma de compreender o próprio ser humano se afirmou. Embora ao longo de quatro séculos tenha havido controvérsias, embates e combates mútuos, atualmente busca-se uma nova caminhada entre as Igrejas Luteranas e a Igreja Católica Romana. A celebração dos 500 anos da Reforma tem-se revelado como oportunidade única para a promoção da unidade cristã.

Palavras-chave: Martim Lutero. 95 teses. Reforma Protestante.

Abstract: The Protestant Reformation impacted Western Christianity with a division, whose repercussion has permeated various fields over the past 500 years. But how would Christianity be if the Protestant Reformation had not occurred? Of course, there is no answer to this. It is true that the Protestant Reformation was somehow favored by situational factors of the sixteenth century, that amplified its impact. These factors have caused the initial protest of Martin Luther through 95 theses about the sale of indulgences to have had an unimaginable range. From then, it has consolidated a new way of understanding the action of God. At the same time, a new way of understanding the human being was asserted. Although during over four centuries there have been disputes, conflicts and mutual fighting, now one seeks for a new walk between Lutheran Churches and the Roman Catholic Church. The celebration of the 500th anniversary of the Reformation has been revealed as an unique opportunity for the promotion of Christian unity.

Keywords: Martin Luther. 95 theses. Protestant Reformation.

* Professor no Centro Universitário Católica de Santa Catarina, Joinville, SC. Graduado em Teologia e Ciências Sociais. Pós-Graduado em Ciências da Religião. Mestre em Teologia. Doutorando em Teologia, PUC-PR, Curitiba, PR. 


\section{Introdução}

Em 2017, celebram-se os 500 anos da Reforma Protestante, uma marca na história do Cristianismo e na sociedade ocidental. Embora tenha sido de caráter religioso-teológica, seu impacto abrangeu o conjunto da sociedade no âmbito cultural, político e econômico. Tornou-se um divisor de águas na história da sociedade ocidental, muito além do domínio eclesiástico. Seu legado está presente no contexto de muitos países, inclusive no Brasil.

De um lado, pode-se lamentar mais essa divisão que ocorreu no seio do Cristianismo, a partir do movimento da Reforma Protestante. Afinal, o mandato evangélico advoga pela unidade cristã (João 17,21). De outro lado, como é comum em situações de crise, o movimento da Reforma provocou inquietações, reformulações e correções no conjunto do Cristianismo. Essas reformulações de ideias e práticas continuam na atualidade, tendo um novo marco de referência no Concílio Vaticano II, no terreno da Igreja Católica Romana. Ou seja, o movimento da Reforma trouxe, cedo ou tarde, a percepção de que é necessário remodelar a forma da mensagem cristã para alcançar as pessoas conforme o tempo em que se vive.

Entrementes, há uma série de diálogos em andamento entre instituições eclesiais provenientes do movimento da Reforma e a Igreja Católica Romana. Diversos entendimentos já foram costurados em pontos doutrinais causadores de ruptura e constrangimento ao longo do tempo. E, no contexto da celebração dos 500 anos, igualmente, uma série de simpósios, congressos e conferências tem tematizado o impacto e o legado da Reforma Protestante para a história do Cristianismo. O Pontifício Conselho para a Unidade dos Cristãos tem-se envolvido intensamente nesse processo, como por exemplo, no Simpósio Ecumênico Internacional Católico-Luterano, numa promoção do Pontifício Ateneu Santo Anselmo, sob o tema "Sinais de perdão. Caminhos de conversão e práticas de penitência. Uma Reforma que interpela a todos"1.

O que se busca não é a anulação de divergências do passado, tampouco tratativas para uma reunificação institucional entre diferentes confissões e denominações cristãs. O horizonte é o diálogo, o entendi-

1 GRATIDÃO, penitência e esperança: chaves para comemoração ecumênica dos 500 anos da Reforma. Disponível em: <http://luteranos.com.br/noticias/gratidao-penitenciae-esperanca-chaves-para-comemoracao-ecumenica-dos-500-anos-da-reforma> . Acesso em: 05 jun. 2016. 
mento e acordos em relação a questões fundamentais no que concerne ao mandato cristão. Ao longo da história do Cristianismo pós-Reforma, ataques e perseguições mútuas ocorreram, deixando um testemunho contraditório na sociedade. Embora novos desafios surjam e diferenças persistam, a superação da vivência e convivência conflitiva é o imperativo no período recente entre diferentes igrejas.

\section{Precursores da Reforma Protestante}

A Reforma Protestante é herdeira de insatisfações e divergências que ao longo da história do Cristianismo foram sendo reprimidas, embora não apagadas. É próprio da mensagem cristã a inquietude e a não conformação com as realidades provisórias da existência. Entretanto, em qualquer situação, contestações provocam reações, reprimendas ou até punições. Isso sempre ocorreu no Cristianismo, em determinados períodos com mais intensidade que em outros. Ou seja, a pluralidade de pensamentos e práticas é algo que acompanha o Cristianismo, apesar de haver predominância de uma ou outra doutrina e prática correspondente.

Ao longo de sua história, houve inúmeras proposições de renovação do Cristianismo, sendo que boa parte delas foram absorvidas sem maiores abalos na estrutura eclesial. O surgimento de ordens monásticas pode ser compreendido como formas de protesto a práticas vigentes e busca de restauração de um Cristianismo mais autêntico, assim como ordens religiosas mendicantes. Essas proposições contrastavam com a oficialidade eclesiástica, mas não obtiveram maiores dificuldades para serem integradas à estrutura eclesial institucionalizada.

Maior repercussão tiveram afirmações advindas de personagens como João Wycliff e João Huss. Wycliff (nasceu por volta de 1320), filósofo e teólogo, professor em Oxford, Inglaterra, teceu críticas intensas em relação às práticas papais e suas consequências eclesiásticas. Conforme Wilhelm Wachholz ${ }^{2}$, o pensamento de Wycliff pode ser caracterizado por três pontos fundamentais: 1) a questão do senhorio - aponta as autoridades eclesiásticas como ilegítimas; 2) ênfase nas Sagradas Escrituras, diminuindo a importância da tradição - defendia a tradução da Bíblia para a língua do povo; 3 ) afirmação da presença real de Deus na Santa Ceia - afirmou que "o corpo e o sangue de Cristo estão verdadeiramente presentes, de

2 WACHHOLZ, Wilhelm. História e Teologia da Reforma: introdução. São Leopoldo: Sinodal, 2010. p. 29. 
maneira 'sacramental' e 'misteriosa', mas o pão e o vinho igualmente estão presentes". Essa questão teria sido decisiva para condená-lo como herege. Embora tenha morrido por razões naturais em 1384, dada a repercussão de seu pensamento, ainda foi condenado pelo Concílio de Constança em 1415 , sendo que seus restos mortais foram desenterrados e queimados ${ }^{3}$.

Huss (nasceu por volta de 1370), também filósofo, teólogo e professor, em Praga, República Checa, pleiteou por uma Igreja firmada no exemplo de Cristo e na simplicidade dos apóstolos ${ }^{4}$. Conforme Henri Daniel-Rops, era dotado de um "verbo inflamado", chegando a afirmar que "o cristão devia basear a sua fé apenas na Palavra de Deus, na Sagrada Escritura, que a Tradição era somente um conjunto de lendas e o primado romano um embuste do Anticristo"s. Diante de seu discurso e a repercussão naquele contexto, desencadeando paixão popular, Huss foi condenado como herege e morto numa fogueira em 1415.

Apesar de estarem situados em contextos geográficos e temporalidades diferentes, o pensamento de Wycliff e Huss manteve seu eco. $\mathrm{O}$ confronto com a hierarquia eclesiástica ficou registrado em diversos documentos, inclusive conciliares. Por isso, num olhar retrospectivo, além de outros como Pedro Valdo (1140-1217), esses personagens podem ser percebidos como precursores do movimento da Reforma. Talvez apenas as condições conjunturais de suas épocas não lhes foram tão favoráveis como foram para Martim Lutero.

\section{O contexto do movimento da Reforma}

O período histórico em que a Reforma Protestante se situa é marcado por crises que abarcam diversas áreas da sociedade de então. Muito além da crise de cunho religioso-teológico-eclesiástico, os âmbitos da economia, política e cultura também estavam em ebulição. Walter Altmann entende que "Lutero viveu na encruzilhada entre o velho e o novo" e pergunta: "Foi ele o representante de uma nova época histórica ou pertenceu ainda à Era Medieval, que se encaminhava para o fim?"'.

3 DANIEL-ROPS, Henri. A lgreja da Renascença e da Reforma: a Reforma Protestante. São Paulo: Quadrante, 1996. p. 154.

4 WACHHOLZ, 2010, p. 30.

5 DANIEL-ROPS, 1996, p. 155.

6 ALTMANN, Walter. Lutero e Libertação: releitura de Lutero em perspectiva latinoamericana. São Leopoldo: Sinodal; São Paulo: Ática, 1994. p. 41. 
Essas observações são feitas considerando novas formas de interação que estavam em gestação no século XVI entre Igreja, espiritualidade, fé, mundo, sociedade, política e economia.

Num panorama ampliado, a sociedade da época defronta-se com elementos tecnológicos novos. A invenção da máquina de impressão, por exemplo, teve reflexos impactantes para a difusão de ideias acerca de assuntos religiosos como também filosóficos em geral, apesar de a possibilidade de leitura à época ainda ser algo restrito. Estima-se que nos últimos 40 anos do século XV tenham sido produzidos mais livros que ao longo de toda a Idade Medieval ${ }^{7}$.

Além disso, o final do século XV registra progressos na navegação de longa distância, a partir do uso de novos instrumentos. Com o uso das novas tecnologias da época, grandes navegações são realizadas, especialmente por Portugal e Espanha com o objetivo de expandir rotas comerciais. Essa questão tem relevância no âmbito econômico da sociedade, uma vez que conduz à consolidação do mercantilismo, em substituição à economia feudal. Acoplado à expansão mercantilista está uma nova forma de colonialismo que alcança "novos mundos", inclusive a América ${ }^{8}$.

Essa expansão mercantilista é fruto de novas constelações políticas da Europa da época. Novas formas de poder estavam sendo engendradas, com novos atores e atrizes entrando em cena. $\mathrm{O}$ enfraquecimento da economia feudal foi abrindo espaço para um novo ator, a burguesia. A burguesia buscava diminuir o poder e os direitos do clero, introduzindo um governo civil nas cidades na tentativa de controlar inclusive a atividade eclesial ${ }^{9}$. Trata-se de um poder econômico conjugado ao político que busca se impor como nova força social.

Nesse período histórico, também estão em andamento os movimentos denominados Renascença e Humanismo. Conforme Agenor Brighenti, "constituem o início de um processo de secularização, marcado por maior estima das realidades terrestres" ${ }^{10}$. Ocorre um resgate de fontes filosóficas, da linguagem e do estilo da Antiguidade Clássica. Ao mesmo

WACHHOLZ, 2010, p. 22.

8 DEZORDI, Lucas Lautert. Fundamentos de Economia. Curitiba: lesde, 2008. p. 9.

9 DREHER, Martin Norberto. A Reforma e as Reformas. In: SCHWAMBACH, Claus; SPEHR, Christopher. (Org.). Reforma e Igreja: estudos sobre a eclesiologia da Reforma na história e na atualidade. São Bento do Sul: União Cristã, 2015. p. 11-31. p. 22. 
tempo, o ser humano passa a ser considerado com mais centralidade no processo histórico. A partir dessa ótica, fica no ar certo grau de desconfiança em relação à autoridade da Igreja.

Nesse sentido, aponta Martin Dreher, "a Reforma deve ser vista como um período entre a Idade Média e a Idade Moderna"11, ou seja, um tempo de transição. Apontando ao contexto religioso-eclesiástico mais restrito, entende que as origens da Reforma podem ser localizadas na crise do papado, em atitudes inadequadas do clero, além de incertezas teológico-dogmáticas.

A crise do papado remonta ao chamado "cisma ocidental" entre 1378 e 1417, período conturbado em que o papado foi exercido por dois e, por fim, por três papas simultaneamente ${ }^{12}$. Posteriormente, o papado é marcado por subornos, vida desregrada e envenenamentos, por exemplo no período 1492-1503, com o Papa Alexandre VI - Rodrigo Borgia. Eram tempos em que o pontificado era alvo de usurpação ${ }^{13}$. No mesmo sentido, boa parte do clero não mantinha em sua vivência a estatura teológica e moral requerida ao ministério.

De outra parte, incertezas teológico-dogmáticas relacionam-se à questão da penitência e das indulgências, enfim, com os meios da graça divina. Tornam-se o ápice das controvérsias, de contestações e divergências. Nessa direção, Wachholz indica que, desde o século XIV, regiões da Europa, de um lado, registravam aumento em sua população, mas, de outro lado, eram afetadas por escassez de mantimentos e surtos de doenças ${ }^{14}$. Nessas situações, o confronto com a morte era constante, sendo que respostas teológicas eram requeridas e formuladas. É fortalecido o entendimento acerca da importância da penitência, do purgatório e da busca por obras de satisfação ou compensação.

Enfim, a soma de uma gama de elementos históricos correntes à época leva tanto a Igreja a justificar sua pregação como também potencializa a contestação às práticas eclesiásticas. A pregação que veio a ser diretamente contestada por Martim Lutero foi a que versava sobre a venda de indulgências, cujo ditado dizia: "Assim que o dinheiro tilinta na caixinha, a alma (em favor de quem se dá a esmola) salta para

\footnotetext{
11 DREHER, 2015, p. 21.

12 WACHHOLZ, 2010, p. 24-26.

13 DREHER, 2015, p. 24.

14 WACHHOLZ, 2010, p. 15.
} 
fora do purgatório"15. O argumento pela venda das indulgências estava revestido por um caráter religioso-teológico, contudo, havia interesses extensamente mundanos nas finalidades pelas quais se buscava a referida arrecadação.

\section{A compreensão da justiça de Deus em Lutero}

O ponto de referência principal da Reforma Protestante tem sido a divulgação em 1517 de 95 teses de contestação à venda das indulgências pela Igreja Católica Romana. Entretanto, da parte de Martim Lutero, há estudos e reflexões teológicas que antecedem a essas teses. Como Professor de Teologia, Lutero vinha se dedicando ao estudo da Bíblia, sendo que por volta de 1515 , havia começado conferências acerca da Carta de Paulo aos Romanos ${ }^{16}$. É a partir dali que vão se assentando algumas compreensões que se transformam em convicções de fé. A pergunta-chave que estava colocada era: como alguém pode vir a se tornar justo perante Deus ou, em última análise, como alguém pode alcançar a salvação?

No contexto do protestantismo luterano, tornou-se célebre a referência à afirmação bíblica, conforme Romanos 1,17: “o justo viverá da fé". O entendimento teológico advindo do aprofundamento do estudo acerca da justiça divina conduziu à convicção de que a justiça de Deus não significa a punição a pessoas pecadoras e a premiação a quem seria "justo". Conforme Justo González,

Refere-se, sim, a que a "justiça" do justo não é obra sua, mas dom de Deus. A "justiça de Deus" é a que tem quem vive pela fé, não porque seja em si mesmo justo, ou porque cumpra as exigências da lei divina, mas porque Deus lhe dá esse dom. A "justificação pela fé" não quer dizer que a fé seja uma obra mais sutil que as boas obras, e que Deus nos pague por essa obra. Quer dizer sim que, tanto a fé como a justificação do pecador, são obras de Deus, dom gratuito ${ }^{17}$.

Ou seja, essa compreensão conduz à afirmação de que todo ser humano, independente de sua forma de viver, é, por princípio, indigno perante Deus. E sua virtuosidade emerge a partir da ação justificadora

\footnotetext{
15 DANIEL-ROPS, 1996, p. 267.

16 GONZÁLEZ, Justo L. A Era dos Reformadores. São Paulo: Vida Nova, 2009. (Uma História llustrada do Cristianismo, v. 6). p. 49.

17 GONZÁLEZ, 1995, p. 50.
} 
de Deus, acolhida com ou pela fé nesse Deus. Não há meio de o ser humano ser justo a não ser pela justificação que vem de Deus. A justiça de Deus seria, pois, uma justiça salvífica e não uma justiça vingativa e punidora do ser humano.

Aparentemente, a compreensão em relação à "justiça de Deus" receberia nova interpretação, diferente da teologia tradicional. Contudo, Giacomo Martina aponta que essa interpretação a essa passagem bíblica não era nova ${ }^{18}$. O que teria ocorrido é uma exacerbação desse conceito ortodoxo da "justificação salvífica através da fé", com a negação da necessidade de cooperação por parte do ser humano. De toda maneira, esse entendimento transformou-se em convicção de fé e, posteriormente, em doutrina no contexto reformista, sendo que até na atualidade, especialmente as Igrejas Luteranas, afirmam esse princípio.

Portanto, é esse o entendimento que já está presente em Martim Lutero acerca do relacionamento entre Deus e o ser humano nos debates teológicos e embates eclesiológicos desenvolvidos a partir de 1517.

\section{Polêmicas e conflitos: as 95 teses}

Em 1517, antes das 95 teses, Lutero havia proposto 97 teses para "Debate sobre a Teologia Escolástica"19. Tratava-se de proposições para discussão no âmbito acadêmico acerca da necessidade de superar o sistema da teologia escolástica. Quer dizer, seu teor é crítico, propugnando por um modo alternativo ao fazer teológico, embora esse modo alternativo ainda não estivesse totalmente claro. Entretanto, conforme Dreher ${ }^{20}$, ninguém apareceu para aprofundar esse debate.

Foi aí que, também em 1517, Lutero lançou outras teses com um tom diferente e com focos diferentes, nesse caso, alcançando repercussão e consequências não imaginadas. São as 95 teses de "Debate para o Esclarecimento do Valor das Indulgências"21. Sem dúvida, não se imaginava o que essas teses para um "Debate" viriam a impulsionar, uma vez que o teor

18 MARTINA, Giacomo. História da Igreja: de Lutero a nossos dias - a era da Reforma. 3. ed. São Paulo: Loyola, 2008. p. 125.

19 LUTERO, Martinho. Obras Selecionadas: os primórdios - escritos de 1517 a 1519. São Leopoldo: Sinodal; Porto Alegre: Concórdia, 1987. p. 15-20.

20 DREHER, Martin Norberto. De Luder a Lutero: uma biografia. São Leopoldo: Sinodal, 2014. p. 86.

21 LUTERO, 1987, p. 22-29. 
dessas teses não parece exageradamente radical. Igualmente, não estava presente a ideia de promover um rompimento na instituição em que Lutero era sacerdote e teólogo. A preocupação é em relação a exageros e abusos que estavam ocorrendo na divulgação e venda de indulgências, tendo como um dos promotores principais o dominicano João Tetzel.

De um lado, há o entendimento de que Lutero mexeu com interesses financeiros que estavam presentes na questão da venda de indulgências. Segundo Martina,

Desde 1507, Júlio II, que tinha dado início aos trabalhos para a construção da nova basílica de São Pedro, tinha concedido uma indulgência como jubileu a quem oferecesse esmolas para essa obra: a iniciativa foi repetida em 1514 por Leão $X^{22}$.

Além disso, consta que na Alemanha houve ainda uma situação peculiar em que questões eclesiásticas e políticas estavam entrelaçadas, sendo que uma trama financeira igualmente estava em pauta, relacionada com a construção da nova Basílica ${ }^{23}$. A partir disso, há historiadores que indicam que uma das causas indiretas da Reforma Protestante teria sido a construção da Basílica de São Pedro em Roma ${ }^{24}$.

De outra parte, é inegável que há um entendimento de caráter teológico presente ao longo das 95 teses, em relação à doutrina das indulgências. Em si, a doutrina das indulgências pressupunha substituição de penalidades impostas pela Igreja, em razão de falhas humanas ou pecados cometidos. Aos poucos, o entendimento foi sendo ampliado, afirmando-se que o papa era senhor em relação a todas as formas de punição temporal, como, por exemplo, o purgatório. Apenas o inferno era compreendido como decorrente da vontade divina, uma vez que era relacionado com algo eterno e inimaginável ${ }^{25}$. $\mathrm{O}$ temor maior das pessoas à época era com o purgatório, mais do que com o inferno.

No Debate intencionado por Lutero, logo nas primeiras teses há menção à importância da penitência, no sentido de arrependimento e reconhecimento da própria pessoa crente de sua culpa ou situação de pecado. A repercussão disso ocorre em "toda sorte de mortificações da

\footnotetext{
22 MARTINA, 2008, p. 130.

23 MARTINA, 2008, p. 131.

24 GONZÁLEZ, 1995, p. 52; WACHHOLZ, 2010, p. 55.

25 DREHER, 2014, p. 90-91
} 
carne"26, ou seja, na vida cotidiana. O papa não teria poder para anular culpas, a não ser para confirmar o perdão de Deus ou, então, para dispensar somente de penas que ele próprio ou os cânones impuseram. Pessoas mortas estariam isentas de penalidades, uma vez que já estariam mortas para as leis canônicas, por isso, não haveria necessidade de venda de indulgências por ou para elas.

Assim, o cunho econômico-financeiro presente na disponibilização de indulgências à época é criticado em diversas dessas teses. Dentre outras desse teor, as teses 27, 28 e 43 afirmam:

27. Pregam doutrina humana os que dizem que, ao tilintar a moeda lançada na caixa, a alma sairá voando [do purgatório].

28. Certo é que, ao tilintar a moeda na caixa, podem aumentar o lucro e a cobiça; a intercessão da Igreja, porém, depende apenas da vontade de Deus.

43. Deve-se ensinar aos cristãos que, dando ao pobre ou emprestando ao necessitado, procedem melhor do que se comprassem indulgências ${ }^{27}$.

A partir de afirmações como essas, torna-se evidente a compreensão da impossibilidade humana naquilo que pertence a outro âmbito, ao âmbito divino. A ação humana tem repercussão apenas no lucro, na cobiça ou no auxílio a alguém necessitado. É negado, portanto, que as indulgências contenham potencial remissivo ou salvífico.

Por mais que essas teses se manifestem contra uma prática autorizada pelo papa, Lutero o defende, indicando que possivelmente o papa nem saberia de abusos que estariam ocorrendo, como apontam as seguintes teses:

50. Deve-se ensinar aos cristãos que, se o papa soubesse das exações dos pregadores de indulgências, preferiria reduzir a cinzas a Basilica de $S$. Pedro do que edificá-la com a pele, a carne e os ossos de suas ovelhas.

51. Deve-se ensinar aos cristãos que o papa estaria disposto - como é seu dever - a dar do seu dinheiro àqueles muitos de quem alguns pregadores de indulgências extraem ardilosamente o dinheiro, mesmo que para isto fosse necessário vender a Basílica de S. Pedro.

26 LUTERO, 1987, p. 23.

27 LUTERO, 1987, p. 24, 26. 
53. São inimigos de Cristo e do papa aqueles que, por causa da pregação de indulgências, fazem calar por inteiro a palavra de Deus nas demais igrejas ${ }^{28}$.

A partir da repercussão da publicação das 95 teses e com o desenrolar político-eclesiástico, essa relação aparentemente tranquila entre Lutero e o papa muda. Surgem confrontos e acusações que culminam com a excomunhão de Lutero em $1521^{29}$. Àquela altura, apesar da excomunhão, o movimento pela renovação da Igreja já encontrava afinidade com boa parcela de humanistas, bem como a simpatia de nacionalistas alemães contra abusos advindos de Roma ${ }^{30}$.

Ainda nessas teses, Lutero aponta para o Evangelho como o verdadeiro tesouro a ser buscado. Por exemplo,

62. O verdadeiro tesouro da Igreja é o santíssimo Evangelho da glória e da graça de Deus.

65. Por esta razão, os tesouros do Evangelho são as redes com que outrora se pescavam homens possuidores de riquezas.

66. Os tesouros das indulgências, por sua vez, são as redes com que hoje se pesca a riqueza dos homens.

68. Entretanto, na verdade elas são as graças mais ínfimas em comparação com a graça de Deus e a piedade da cruz ${ }^{31}$.

Ou seja, já no princípio do movimento reformista, as Escrituras Sagradas são referência para a afirmação da posição de Lutero, sendo que, posteriormente, são postas como autoridade fundamental e única. É a autoridade das Sagradas Escrituras que é invocada na Dieta de Worms, em 1521, quando Lutero devia desdizer suas afirmações críticas até então elaboradas. Afirmou o Reformador:

Se eu não for refutado através de testemunhos da Escritura ou por um argumento da razão bem claro, então eu fui vencido pelas palavras bíblicas que eu citei. E como minha consciência está cativa nas palavras de Deus, não posso e não quero revogar nada, pois é perigoso e impossível fazer algo contra a consciência. Deus me ajude, amém! $!^{32}$.

28 LUTERO, 1987, p. 26. 
Enfim, a divulgação dessas 95 teses em 1517 se constituiu como o marco do início da Reforma Protestante. Embora não fosse o objetivo promover uma cisão no contexto eclesial, a conjunção de inúmeros fatores conduziu a isso. Após a excomunhão de Lutero, o movimento reformista tomou rumos cada vez mais irreconciliáveis em relação à Igreja Católica Romana. Foi sendo erigido um modo autônomo de Igreja, com formulações doutrinárias próprias, tendo por base apenas as Escrituras Sagradas, refutando a autoridade da tradição e do magistério eclesial até então vigentes.

\section{Novas ênfases teológicas, novo modo de ser lgreja}

Está claro que, de teólogo católico, Lutero vai se tornando ou vai sendo tornado teólogo protestante - ou, originalmente, teólogo "evangélico"33. Em relação a suas elaborações de pensamento e escritos teológicos que se seguem até ao final de sua vida em 1546, há muitas interpretações acerca do que seriam os pontos centrais. No campo protestante luterano há convergências interpretativas, embora nem sempre unânimes. O ponto de vista de cada estudioso acerca do legado de Lutero varia de acordo com o locus a partir do qual o olhar interpretativo é lançado.

Por exemplo, Walther von Loewenich compreende que a marca da teologia de Lutero é ser "teologia da cruz" ${ }^{34} \mathrm{em}$ oposição ao que é a mencionada "teologia da glória". A referência é uma abordagem que Lutero desenvolveu em 1518, chamado "O Debate de Heidelberg"35. Ali é defendida a tese de que a verdadeira teologia reconhece Deus a partir do Cristo crucificado, no sofrimento e na fraqueza, e não no triunfo, glória e poder. Loewenich entende que essa compreensão se tornou a marca que perpassa todo pensar teológico e eclesiológico de Lutero. "Lutero considerou cruz e sofrimento o tesouro mais precioso da igreja. [...] A verdadeira igreja é, muito antes, uma igreja de mártires" ${ }^{36}$. É nesse sentido que no escrito "Dos

sobre a compreensão protestante da Escritura Sagrada na história e na atualidade. São Bento do Sul: União Cristã, 2016. p. 85-102. p. 86.

33 EBELING, Gerhard. O Pensamento de Lutero: uma introdução. São Leopoldo: Sinodal, 1988. p. 26.

34 LOEWENICH, Walther von. A Teologia da Cruz de Lutero. São Leopoldo: Sinodal, 1987. p. 14.

35 LUTERO, 1987, p. 37-54.

36 LOEWENICH, 1987, p. 127. 
Concílios e da Igreja" ${ }^{37}$ Lutero estaria mencionando a cruz como um dos sinais para o reconhecimento do que é a verdadeira Igreja.

Altmann lembra a dificuldade para apontar o que seriam os traços centrais do pensamento de Lutero. De todo modo, menciona que, em Lutero, fundamental é a "ênfase na autoridade da Escritura e a exclusividade desta como fonte de doutrina e fe'" 38 . De acordo com Altmann, a partir dali decorre a doutrina central acerca da "justificação pela fé". Variante dessa doutrina é a compreensão da liberdade cristã ou liberdade evangélica: a partir da fé em Cristo, a pessoa cristã é livre e a ninguém sujeita, de um lado; por outro lado, a partir da fé, a pessoa cristã é sujeita a todas as pessoas, com o compromisso de serviço decorrente da fé em Cristo. Cita que outro aspecto da teologia de Lutero é a theologia crucis, mencionada anteriormente. E, lembra ainda, há o que pode ser chamado de "nova santidade" em relação à vida da pessoa cristã: ou seja, a vivência da fé no cotidiano, "onde hoje se faz história", num modo ativo de vivência da fé em meio aos desafios da atualidade ${ }^{39}$.

De outra parte, Dreher entende que no "centro da teologia de Lutero, está o primeiro mandamento do Decálogo", afirmando que a pessoa cristã deve "temer e amar a Deus e confiar nele sobre todas as coisas" descobertas de Lutero teriam esse referencial. Conforme Dreher, é dessa compreensão que decorre a doutrina acerca da justiça de Deus, a distinção hermenêutica entre lei e evangelho, a teologia da cruz como o lugar onde Deus quer ser encontrado, a Bíblia como autoridade única na Igreja, a eclesiologia que reconhece a verdadeira Igreja a partir da pregação do Evangelho e da prática dos sacramentos do Batismo e da Ceia do Senhor, bem como com uma ética preocupada com a sobrevivência em tempos difíceis ${ }^{41}$.

Quer dizer, há diferentes abordagens em relação ao pensamento de Lutero sem que constituam contradição. Contemplam aspectos a partir de diferentes perspectivas. Em síntese, a partir do pensamento de Lutero, o que se consolidou como sustentação da doutrina da Igreja Luterana são os “quatro somentes": solus Christus, sola gratia, sola Scriptura, sola fides ${ }^{42}$. A

LUTERO, Martinho. Obras Selecionadas: debates e controvérsias, I. São Leopoldo: Sinodal; Porto Alegre: Concórdia, 1992. p. 421.

ALTMANN, 1994, p. 282.

ALTMANN, 1994, p. 283-289.

DREHER, 2015, p. 33-34.

41 DREHER, 2015, p. 33-46.

42 VOIGT, Emílio. Quem Somos Nós?: princípios da fé cristã e da confessionalidade luterana. São Leopoldo: Sinodal, 2014. p. 89-99. A ordem desses "somentes" pode variar de acordo com diferentes autores ou autoras. 
afirmação de Jesus Cristo como único mediador entre o ser humano e Deus somente Cristo - conduziu a diferenciações visíveis nas Igrejas oriundas do movimento da Reforma. Em sua forma mais radical, naquela época, inclusive levou grupos reformistas a destruir imagens de santos ou representações de Cristo em diversos templos. Em boa medida, o interior dos templos de Igrejas Protestantes reflete esse princípio ainda na atualidade, restringindo simbologias, sendo que, em muitos casos, a própria cruz presente no altar encontra-se "vazia" - sem a afixação do Cristo crucificado.

Outro princípio é que somente a Escritura Sagrada contém as verdades reveladas por Deus, sendo dispensável o auxílio da tradição ou da mediação do magistério eclesial para sua interpretação e compreensão ${ }^{43}$. Segundo Korsch, uma "das convicções mais firmes da Reforma do séc. $\mathrm{XVI}$ reside no fato de que, em todas as questões teológicas, no final, quem decide é a Escritura Sagrada" ${ }^{44}$. Ao longo da argumentação de Lutero, seja em seus escritos teológicos como em sua defesa pessoal diante das autoridades a que devia responder, o apelo à Escritura Sagrada está sempre presente. $\mathrm{O}$ entendimento da autoridade das Escrituras motivou sua tradução para a língua alemã à época, e se tornou um elemento presente ao longo da história não apenas nos templos, mas na casa das famílias seguidoras de alguma tradição advinda do movimento da Reforma.

Já o princípio de que somente pela graça o ser humano tem possibilidade de se tornar justo ou justificado perante Deus representa rejeição a mediações externas instituídas pelo próprio ser humano ${ }^{45}$. As indulgências, por exemplo, são rechaçadas a partir desse princípio. Está embutida nessa compreensão a concepção de que o ser humano por si e em si não tem potencial para efetuar sua redenção. Se a redenção é uma possibilidade, o é unicamente por ação graciosa da parte de Deus. A própria Igreja, mesmo com sua hierarquia sacralmente instituída, não consegue efetuar e efetivar o que pertence unicamente ao âmbito divino. Com isso, as hierarquias em grande parte das Igrejas oriundas da Reforma são tidas como importantes em termos organizativos, mas sem um caráter mediador.

E o princípio “somente pela fé” é expressão da graça de Deus que permite o surgimento da fé. E é somente pela fé em Cristo que se pode

\footnotetext{
43 MARTINA, 2008, p. 126.

44 KORSCH, 2016, p. 86

45 MARTINA, 2008, p. 129.
} 
acolher os bens oferecidos por Deus, como o perdão e a justificação. $\mathrm{O}$ entendimento é que o ser humano é simul peccator et justus ${ }^{46}$, ou seja, pecador a partir de sua natureza limitada, mas simultaneamente justo a partir da graça de Deus, apreendida e apreensível somente pela fé. Nenhuma obra meritória é possível para acolher o que apenas pela fé se pode receber. Ao mesmo tempo, isso não significa passividade humana absoluta. Boas obras surgem na ação humana "como consequência da justificação, não como condição para obtê-la" 47 .

Enfim, a partir dos inúmeros escritos teológicos de Lutero emergem interpretações variadas, que se complementam e servem de sustentação doutrinária para as Igrejas oriundas da Reforma Protestante em geral, e para as Igrejas Luteranas em particular. E é importante lembrar que, dentro do próprio movimento da Reforma, compreensões teológico-teóricas dissonantes com consequências práticas existiram e se impuseram. Embora em torno de Martim Lutero tenha se configurado o movimento reformista majoritário, diversas outras tendências com menos ou mais radicalidade passaram a percorrer caminhos peculiares. As principais divergências se localizaram entre teólogos como Ulrico Zwínglio, João Calvino, Filipe Melanchton, Tomas Müntzer, Menno Simons, Martim Bucer, além do anglicanismo que se formulou de modo particular na Inglaterra ${ }^{48}$.

\section{Considerações finais}

Entre Igrejas Luteranas e a Igreja Católica Romana tem havido intenso diálogo ao longo dos últimos 50 anos, tanto no contexto brasileiro quanto em nível mundial. Em nível de Brasil, o ano de 1974 marca a formação da "primeira comissão de diálogo bilateral [...] com a finalidade de estudar questões sobre doutrina e ação pastoral entre as respectivas confissões" "49. Anteriormente, na década de 1960, já vinham sendo dado passos "interconfessionais", a partir de entidades com GERT (Grupo Ecumênico de Reflexão Teológica) em 1957, SICA (Serviço Interconfessional de Aconselhamento) em 1969 e CECA (Centro Ecumênico de Evangelização, Capacitação e Assessoria)

46 MARTINA, 2008, p. 127.

47 VOIGT, 2014, p. 98.

48 MURAD, Afonso; GOMES, Paulo Roberto; RIBEIRO, Súsie. A Casa da Teologia: introdução ecumênica à ciência da fé. São Paulo: Paulinas; São Leopoldo: Sinodal, 2010. p. 103-113. WACHHOLZ, 2010, p. 81-89.

49 WOLFF, Elias. Caminhos do Ecumenismo no Brasil: história, teologia, pastoral. São Paulo: Paulus, 2002. p. 119. 
em $1973^{50}$. Essas foram iniciativas na região sul do Brasil, especificamente no Rio Grande do Sul. Ao longo desses anos, importantes resultados têm sido alcançados no sentido de dirimir conflitos, tanto em âmbito institucional quanto em relacionamentos cotidianos, "na base", entre pessoas dessas diferentes confessionalidades. Dentro disso, por exemplo, está a aceitação mútua de batismos e a celebração conjunta de bênçãos matrimoniais.

Em nível internacional, a partir de contatos entre luteranos e católicos no Concílio Vaticano II, desde $1965^{51}$ ou $1967^{52}$ há um grupo de diálogo acerca de aspectos que historicamente têm sido controversos, relativos ao movimento da Reforma. As instâncias de diálogo passaram a ser a Federação Luterana Mundial (FLM) e o Pontifício Conselho para a Promoção da Unidade dos Cristãos (PCPUC). Também em âmbito internacional diversos resultados positivos vêm sendo alcançados. Por exemplo, em 1980, por ocasião da celebração dos 450 anos do documento "Confissão de Augsburgo" - referência dentro da confessionalidade luterana - houve um posicionamento conjunto, iniciando um reconhecimento mútuo de culpa em relação à separação entre Igrejas proveniente do movimento da Reforma ${ }^{53}$. Igualmente em 1983, por ocasião da celebração dos 500 anos de nascimento de Martim Lutero, esse diálogo internacional afirmou conjuntamente temas essenciais da fé cristã.

Ponto auge do diálogo internacional entre católicos e luteranos veio a ser a "Declaração Conjunta sobre a Doutrina da Justificação" 54 , em 1989. Essa Declaração considera toda caminhada ecumênica havida e "abarca um consenso em verdades básicas da doutrina da justificação e mostra que os desdobramentos distintos ainda existentes não constituem mais motivo de condenações doutrinais". Ou seja, consolida um olhar fraterno mútuo e expande a perspectiva da unidade visível no "Corpo de Cristo", cujo modelo permanece em aberto.

50 SCHMIDT, Ervino. A Comissão Nacional Católico-Luterana. Retrospectiva e Desafios. Encontros Teológicos: revista da FACASC e do ITESC, Florianópolis, ano 25, n. 1, p. 93-102, 2010. p. 97-98.

51 WEBER, Bertholdo. O Diálogo Católico-Luterano Internacional. Resumo Histórico. Estudos Teológicos. São Leopoldo, ano 22, n. 3, p. 271-282, 1982. p. 271;

52 PONTIFÍCIO Conselho Para a Promoção da Unidade dos Cristãos \& Federação Luterana Mundial. Do Conflito à Comunhão: comemoração conjunta católico-luterana da Reforma em 2017. Relatório da Comissão Luterana - Católico-Romana para a Unidade. Brasília: Edições CNBB; São Leopoldo: Sinodal, 2015.

53 WEBER, 1982, p. 272.

54 DECLARAÇÃO Conjunta sobre a Doutrina da Justificação. Disponível em: <http:// www.vatican.va/roman_curia/pontifical_councils/chrstuni/documents/rc_pc_chrstuni_doc_31101999_cath-luth-joint-declaration_po.html>. Acesso em: 09 jun. 2016. 
Na atualidade, tendo em vista a celebração dos 500 Anos da Reforma Luterana, tendo por base $\mathrm{o}$ ano de 1517, ano da divulgação das 95 teses acerca das indulgências por Lutero, o documento de referência é "Do Conflito à Comunhão: comemoração conjunta católico-luterana da Reforma em 2017. Relatório da Comissão Luterana - Católico-Romana para a Unidade", já citado. Constitui-se na tentativa de reescrever a história do movimento da Reforma, superando controvérsias. Não busca ocultar ou eliminar divergências, mas vislumbra um caminho para consideração mútua, de "irmãos separados", quem sabe, para "irmãos não compreendidos" ou para simplesmente "irmãos de fé no mesmo Cristo". As atitudes recentes do Papa Francisco manifestam claro testemunho nessa direção. Enfim, há que se considerar positivamente os passos dados "a fim de que todos sejam um".

\section{Referências}

ALTMANN, Walter. Lutero e Libertação: releitura de Lutero em perspectiva latino-americana. São Leopoldo: Sinodal; São Paulo: Ática, 1994.

BRIGHENTI, Agenor. A Igreja Perplexa: a novas perguntas, novas respostas. São Paulo: Paulinas, 2004.

DANIEL-ROPS, Henri. A Igreja da Renascença e da Reforma: a Reforma Protestante. São Paulo: Quadrante, 1996.

DECLARAÇÃO Conjunta sobre a Doutrina da Justificação. Disponível em: <http://www.vatican.va/roman_curia/pontifical_councils/chrstuni/ documents/rc_pc_chrstuni_doc_31101999_cath-luth-joint-declaration_ po.html>. Acesso em: 09 jun. 2016.

DEZORDI, Lucas Lautert. Fundamentos de Economia. Curitiba: Iesde, 2008.

DREHER, Martin Norberto. A Reforma e as Reformas. In: SCHWAMBACH, Claus; SPEHR, Christopher. (Org.). Reforma e Igreja: estudos sobre a eclesiologia da Reforma na história e na atualidade. São Bento do Sul: União Cristã, 2015. p. 11-31.

DREHER, Martin Norberto. De Luder a Lutero: uma biografia. São Leopoldo: Sinodal, 2014.

EBELING, Gerhard. O Pensamento de Lutero: uma introdução. São Leopoldo: Sinodal, 1988.

GONZÁLEZ, Justo L. A Era dos Reformadores. São Paulo: Vida Nova, 2009. (Uma História Ilustrada do Cristianismo, v. 6). 
GRATIDÃO, penitência e esperança: chaves para comemoração ecumênica dos 500 anos da Reforma. Disponível em: $<$ http://luteranos.com. br/noticias/gratidao-penitencia-e-esperanca-chaves-para-comemoracaoecumenica-dos-500-anos-da-reforma>. Acesso em: 05 jun. 2016.

KORSCH, Dieter. Sola Scriptura. O princípio escriturístico da pregação evangélica. In: SCHWAMBACH, Claus \& SPEHR, Christopher (Org.). Reforma e Bíblia: estudos sobre a compreensão protestante da Escritura Sagrada na história e na atualidade. São Bento do Sul: União Cristã, 2016. p. 85-102.

LOEWENICH, Walther von. A Teologia da Cruz de Lutero. São Leopoldo: Sinodal, 1987.

LUTERO, Martinho. Obras Selecionadas: debates e controvérsias, I. São Leopoldo: Sinodal; Porto Alegre: Concórdia, 1992.

LUTERO, Martinho. Obras Selecionadas: os primórdios - escritos de 1517 a 1519. São Leopoldo: Sinodal; Porto Alegre: Concórdia, 1987.

MARTINA, Giacomo. História da Igreja: de Lutero a nossos dias - a era da Reforma. 3. ed. São Paulo: Loyola, 2008.

MURAD, Afonso; GOMES, Paulo Roberto; RIBEIRO, Súsie. A Casa da Teologia: introdução ecumênica à ciência da fé. São Paulo: Paulinas; São Leopoldo: Sinodal, 2010.

PONTIFÍCIO Conselho Para a Promoção da Unidade dos Cristãos \& Federação Luterana Mundial. Do Conflito à Comunhão: comemoração conjunta católico-luterana da Reforma em 2017. Relatório da Comissão Luterana-Católico-Romana para a Unidade. Brasília: Edições CNBB; São Leopoldo: Sinodal, 2015.

SCHMIDT, Ervino. A Comissão Nacional Católico-Luterana: retrospectiva e desafios. Encontros Teológicos: revista da FACASC e do ITESC, Florianópolis, ano 25, n. 1, p. 93-102, 2010.

WACHHOLZ, Wilhelm. História e Teologia da Reforma: introdução. São Leopoldo: Sinodal, 2010.

WEBER, Bertholdo. O Diálogo Católico-Luterano Internacional: resumo histórico. Estudos Teológicos. São Leopoldo, ano 22, n. 3, p. 271-282, 1982.

WOLFF, Elias. Caminhos do Ecumenismo no Brasil: história, teologia, pastoral. São Paulo: Paulus, 2002.

E-mail do Autor: ir.mann@hotmail.com. 